\title{
The Quantitative Dependence of Reducibility on Mineralogical Composition in Iron Ore Sinters (Blast Furnace Sinters)
}

\author{
H. Krztoń*, J. Stecko And Z. Kania \\ Instytut Metalurgii Żelaza, K. Miarki 12-14, 44-100 Gliwice, Poland
}

\begin{abstract}
Reducibility is a parameter which describes the ability of oxygen, combined with iron, to be removed from iron ore sinters by a reducing gas used in a blast furnace, and is often characterized by a $\mathrm{Fe}^{2+}$ content in a sinter. In sinters, iron at $\mathrm{Fe}^{2+}$ valence can occur in various types of minerals, which differ in values of reducibility. The set of sinters with the reducibility from $0.63 \% / \mathrm{min}$ to $1.49 \% / \mathrm{min}$, prepared in the different laboratory conditions, were examined in terms of their mineral composition. The quantitative dependences between the fractions of the individual mineral constituents of the sinters and the values of reducibility were sought. The increase of the reducibility was correlated with a decrease of the content of magnetite and a rise of the fraction of hematite.
\end{abstract}

DOI: 10.12693/APhysPolA.130.1147

PACS/topics: 61.05.cp, 89.20.Bb

\section{Introduction}

One of the most important parameters of the iron ore sinters, besides chemical composition, basicity and thermoplastic properties [1-3] — is their reducibility. Reducibility is the ability of oxygen, combined with iron, to be removed from iron ores, sinters or pellets by a reducing gas used in a blast furnace $-\mathrm{C}, \mathrm{CO}$, or $\mathrm{H}_{2}$. Reducibility has an effect on the blast furnace process and is often characterized by the content of $\mathrm{Fe}^{2+}$ in the sinter (recalculated as $\mathrm{FeO}$ content). The higher $\mathrm{Fe}^{2+}$ content, the lower reducibility (Fig. 1) [4]. Nowadays, the optimal level of $\mathrm{Fe}^{2+}$ is kept typically as 5 to $7 \mathrm{wt} \%$. The other important factors which are responsible for the quality of a sinter are: its texture and in particular - its porosity. The porosity can affect the reducibility so strongly that sinters with different mineralogy but similar porosity can have the same reducibility values. Iron at $\mathrm{Fe}^{2+}$ valence can occur in various types of minerals, in simple iron oxides as wustite and also in more complex compounds as silicates or iron ferrites. The resultant reducibility of

TABLE I

The reducibility of the individual synthetic mineral components of the sinters. The parameters of the reduction process were the same for each mineral: temperature $900^{\circ} \mathrm{C}$, time - $40 \mathrm{~min}$ and the atmosphere of pure $\mathrm{CO}$ [5].

\begin{tabular}{c|c}
\hline \hline Mineral & Reducibility [\%/min] \\
\hline hematite $\alpha-\mathrm{Fe}_{2} \mathrm{O}_{3}$ & 49.4 \\
$4 \mathrm{CaO} \cdot \mathrm{Al}_{2} \mathrm{O}_{3} \cdot \mathrm{Fe}_{2} \mathrm{O}_{3}$ & 23.4 \\
magnetite $\mathrm{Fe}_{3} \mathrm{O}_{4}$ & 25.5 \\
$\mathrm{Fe}_{2} \mathrm{SiO}_{4}$ & 5.0 \\
$\mathrm{CaO} \cdot \mathrm{Fe}_{2} \mathrm{O}_{3}$ & 49.2 \\
$\left(\mathrm{Ca}_{0.65} \mathrm{Fe}_{0.35}\right)_{2} \mathrm{SiO}_{4}$ & 9.4 \\
$2 \mathrm{CaO} \cdot \mathrm{Fe}_{2} \mathrm{O}_{3}$ & 25.5 \\
$\mathrm{CaFeSiO}$ & 12.8
\end{tabular}

*corresponding author; e-mail: hkrzton@imz.pl

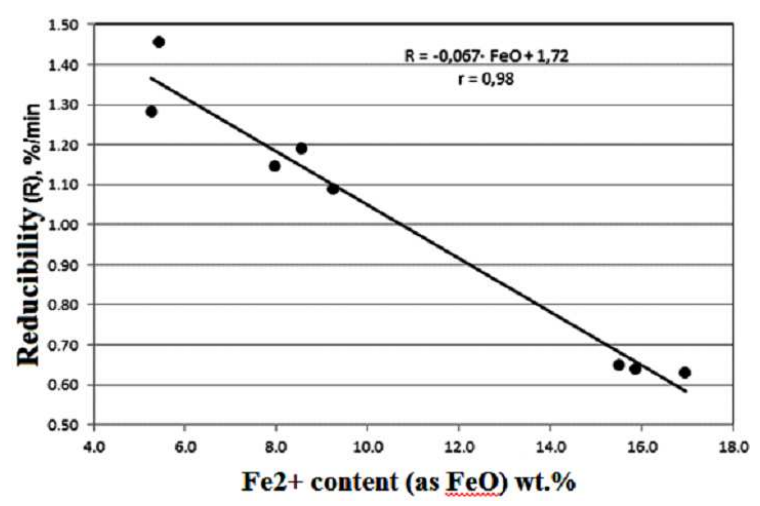

Fig. 1. The relation between reducibility and $\mathrm{Fe}^{2+}$ content in sinters [4].

a sinter is, in fact, a sum of reducibilities of individual mineral components. Such minerals like iron ferrites and iron oxides have got the highest values of reducibility (Table I); in turn the mineral components which lower the reducibility are silicate phases and also the amorphous component (silicate glass) [5].

The aim of this work was to determine the quantitative mineralogical characteristics of sinters in correlation with their (sinters') values of reducibility. The quantification of the mineral constituents of a sinter became much easier after the application of the Rietveld method [6] to analyze multicomponent materials [7-9]. There are two main advantages of the Rietveld method in studying such systems; firstly, a detailed analysis of a difference plot verifies the results of a phase identification. Secondly, the possibility of including all reflections into a process of fitting of a theoretical model to an experimental data enables to overcome the overlapping problems, to minimize the preferred orientation effects and to take into account the minerals of small contents (about $1 \mathrm{wt} \%$ ). Moreover, the changes in the positions of the reflections due to changes of lattice parameters (usually because of the substitution of the lattice atoms by some foreign atoms) and the shape and width of the reflections are 
easily modelled in most cases. Quantification can also be successfully used to determine $\mathrm{Fe}^{2+}$ content in iron ore sinter [9].

Additionally, the microabsorption contrast, often occurring in multiphase materials, can also be included in calculations [8].

\section{Experimental}

The examined sinters are characterized in Table II (the preparation conditions) and in Table III (the chemical composition). The sinters were prepared in various laboratory and charge conditions, with the values of reducibility from 0.63 to $1.49 \% / \mathrm{min}$. Three of the examined sinters, namely 4, 5, and 6 , were prepared using the upper layer idea which is described in comment to Fig. 2. The effect of porosity and texture on the reducibility value of the sinters was eliminated by powdering the sinters to the grain size below $10 \mu \mathrm{m}$.
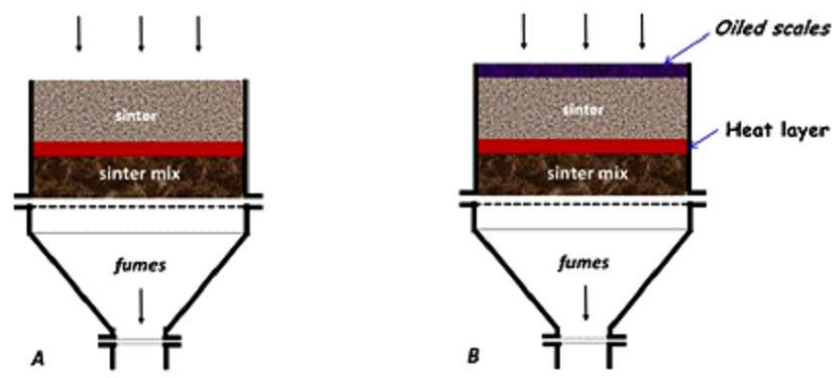

Fig. 2. The idea of sintering with the upper layer with oily scales (laboratory conditions): (A) standard sintering iron ore, (B) sintering of iron ore with an extra layer of oily scales. The idea of the (B) case consists in applying a well-defined portion of by-products containing oily substances on a surface of a produced sinter layer of a precisely determined thickness. The ignition of such located oily layer of the scales causes that the exhaust gases from the combustion of hydrocarbons contained in the oil, pass through a heat zone $\left(1250 \div 1320^{\circ} \mathrm{C}\right)$, formed in a sintered standard mixture. This should cause the total combustion of hydrocarbons contained in oily by-products. Thus the layer of heat generated in the sinter is a kind of a filter which prevents an increase in emission of non-combusted substances into the environment.

The XRD data were collected on a Philips PW 1140 diffractometer with Co radiation and a proportional counter. A graphite monochromator was used on the diffracted beam. The power conditions of the experiments were $40 \mathrm{kV}$ and $40 \mathrm{~mA}$. The scan range was $10^{\circ}$ $90^{\circ} 2 \theta$ with a step size of $0.05^{\circ} 2 \theta$ and time/step $=10 \mathrm{~s}$. The identification of minerals in all sinters were done according to ICDD PDF-4+ base. The fractions of the individual, crystalline minerals were calculated using the $\mathrm{Ri}$ etveld method and the Siroquant software [8]. The fraction of the amorphous component was determined using the addition of certified powdered corundum (Standard Reference Material No 676a, produced by National Institute for Standards and Technology in the USA).
TABLE II

The characteristics of laboratory sinters used in this research study.

\begin{tabular}{|c|c|c|c|c|}
\hline Sinter & $\begin{array}{c}\text { Reducibility } \\
{[\% / \mathrm{min}]}\end{array}$ & $\begin{array}{l}\mathrm{Fe}_{\text {total }} \\
{[\mathrm{wt} \%]}\end{array}$ & $\begin{array}{c}\mathrm{FeO} \\
{[\mathrm{wt} \%]}\end{array}$ & Process description \\
\hline 1 & 0.63 & 57.15 & 16.95 & $\begin{array}{l}\text { comparative sinter with } \\
\text { a high content of } \mathrm{FeO}\end{array}$ \\
\hline 2 & 0.64 & 57.01 & 15.86 & $\begin{array}{l}\text { sinter with an addition } \\
\text { of } 5 \text { wt } \% \text { of burnt lime }\end{array}$ \\
\hline 3 & 0.65 & 56.87 & 15.50 & sinter with limestone \\
\hline 4 & 1.09 & 56.88 & 9.24 & $\begin{array}{l}\text { sinter with the upper } \\
\text { layer of thickness of } \\
30 \mathrm{~mm} \text {, containing oily } \\
\text { scales (recycling of com- } \\
\text { bustion gas) }\end{array}$ \\
\hline 5 & 1.15 & 56.44 & 7.97 & $\begin{array}{l}\text { sinter with the upper } \\
\text { layer of thickness of } \\
20 \mathrm{~mm} \text {, containing oily } \\
\text { scales (recycling of com- } \\
\text { bustion gas) }\end{array}$ \\
\hline 6 & 1.19 & 55.71 & 8.55 & $\begin{array}{l}\text { sinter with the upper } \\
\text { layer of thickness of } \\
40 \mathrm{~mm} \text {, containing oily } \\
\text { scales (recycling of com- } \\
\text { bustion gas) }\end{array}$ \\
\hline 7 & 1.28 & 55.91 & 5.26 & $\begin{array}{l}\text { sinter with an addi- } \\
\text { tion of magnesium sili- } \\
\text { cate of olivine structure } \\
\text { (instead of magnesium } \\
\text { carbonate) }\end{array}$ \\
\hline 8 & 1.46 & 56.05 & 5.44 & $\begin{array}{l}\text { comparative sinter with } \\
\text { a low content of } \mathrm{FeO}\end{array}$ \\
\hline
\end{tabular}

The chemical composition of the sinters.

TABLE III

\begin{tabular}{c|c|c|c|c|c|c|c|c}
\hline \hline & 1 & 2 & 3 & 4 & 5 & 6 & 7 & 8 \\
\cline { 2 - 9 } Sinter & \multicolumn{7}{|c}{ Content [wt\%] } \\
\hline $\mathrm{Fe}_{\text {total }}$ & 56.42 & 56.31 & 56.01 & 55.56 & 55.12 & 54.97 & 55.31 & 55.03 \\
$\mathrm{FeO}$ & 16.56 & 15.22 & 15.15 & 7.97 & 6.34 & 6,34 & 4.65 & 5.16 \\
$\mathrm{CaO}$ & 10.15 & 10.13 & 10.26 & 9.89 & 10.55 & 10,58 & 11.64 & 10.82 \\
$\mathrm{SiO}_{2}$ & 6.43 & 6.34 & 6.67 & 7.86 & 7.95 & 8,35 & 6.38 & 7.87 \\
$\mathrm{MgO}$ & 1.33 & 1.34 & 1.33 & 1.16 & 1.19 & 1.12 & 1.45 & 1.23 \\
$\mathrm{Al}_{2} \mathrm{O}_{3}$ & 0.79 & 0.78 & 0.79 & 1.37 & 1.42 & 0.88 & 0.72 & 0.82 \\
$\mathrm{P}_{2} \mathrm{O}_{5}$ & - & - & - & 0.046 & 0.046 & 0.069 & 0.088 & 0.049 \\
$\mathrm{Mn}$ & 0.140 & 0.140 & 0.130 & 0.100 & 0.100 & 0.140 & 0.170 & 0.094 \\
$\mathrm{Na}_{2} \mathrm{O}$ & - & - & - & 0.100 & 0.093 & 0.098 & - & 0.084 \\
$\mathrm{~K}_{2} \mathrm{O}$ & - & - & - & 0.042 & 0.039 & 0.042 & - & 0.034 \\
$\mathrm{~S}$ & - & - & - & 0.058 & 0.06 & 0.066 & - & 0.060 \\
$\mathrm{Zn}$ & - & - & - & 0.014 & 0.011 & 0.015 & - & 0.023 \\
basicity & 1.58 & 1.60 & 1.54 & 1.26 & 1.33 & 1.27 & 1.82 & 1.37 \\
$\mathrm{CaO} / \mathrm{SiO}_{2}$ & & & & & & & &
\end{tabular}

\section{Results and discussion}

No significant differences in qualitative phase composition of the sinters were observed - the main components were iron oxides i.e. magnetite $\mathrm{FeO} \cdot \mathrm{Fe}_{2} \mathrm{O}_{3}(\mathrm{M})$ and hematite $\alpha-\mathrm{Fe}_{2} \mathrm{O}_{3}$ (H) (Fig. 3, Fig. 4a), and various kinds of silicates. The theoretical model of the sample consisted of 11 crystalline minerals (content in wt\%): 
magnetite $\mathrm{M}-32.1$, hematite $\mathrm{H}-8.1$, wustite $\mathrm{W}-$ 0.8 , quartz $\mathrm{Q}-0.7$, hedenbergite $\mathrm{Hd}-1.7$, dicalcium silicates $\mathrm{C} 2 \mathrm{~S}(\alpha-0.6, \beta-3.8, \gamma-0.7)$, kirschsteinite $\mathrm{K}-1.5$, SFCA -0.6 , SFCA-1 - 0.4, amorphous - 49.0. The content of wustite $\mathrm{Fe}_{0.9} \mathrm{O}$ was at almost the same level in all examined sinters (Fig. 3, Fig. 4a). In every sinter, dicalcium silicates $2 \mathrm{CaO} \cdot \mathrm{SiO}_{2}$ $(\mathrm{C} 2 \mathrm{~S})$ were present, the dominant type was $\beta 2-\mathrm{CaO} \cdot \mathrm{SiO}_{2}$ (larnite) whose content varied from $2.2 \mathrm{wt} \%$ in the sinter 2 to $8.7 \mathrm{wt} \%$ in the sinter 4 . The fractions of other polymorphs did not exceed $1.0 \mathrm{wt} \%$. Two kinds of calcium iron silicates were identified: hedenbergite (enriched in $\mathrm{Fe}^{2+}$ ) $\mathrm{Ca}_{0.7} \mathrm{Fe}_{1.7} \mathrm{Si}_{2} \mathrm{O}_{6}$ and kirschsteinite $\mathrm{CaFeSiO}_{4}$. Their quantitative relation with the reducibility is shown in Fig. 4b. The small amounts of slag phases SFCA $\left(\mathrm{Ca}_{2.3} \mathrm{Mg}_{0.8} \mathrm{Al}_{1.5} \mathrm{Fe}_{8.3} \mathrm{Si}_{1.1} \mathrm{O}_{20}\right)$ and SFCA$1\left(\mathrm{Ca}_{3.18} \mathrm{Fe}_{15.48} \mathrm{Al}_{1.34} \mathrm{O}_{28}\right)$ were determined (Fig. 4b). The amorphous component was detected and its fraction calculated (Fig. 4b) using a known addition of corundum.

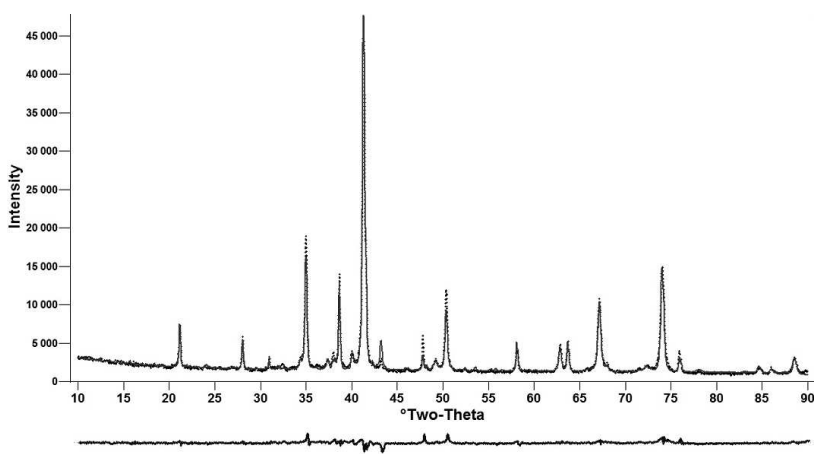

Fig. 3. The result of the Rietveld refinement of the experimental data of the minerals of the sinter with $R=0.63 \% / \mathrm{min}$, with $R_{\text {pattern }}$ factor $=0.065$ [10] and $\chi^{2}=6.30[11,12] ; \chi^{2}$ defined as the ratio $R_{\text {weightedprofile }} / R_{\text {expected. }}$ In multiphase systems, multiplying least-squares errors by $\chi$ gives the value of uncertainty of the calculated results of contents [12].

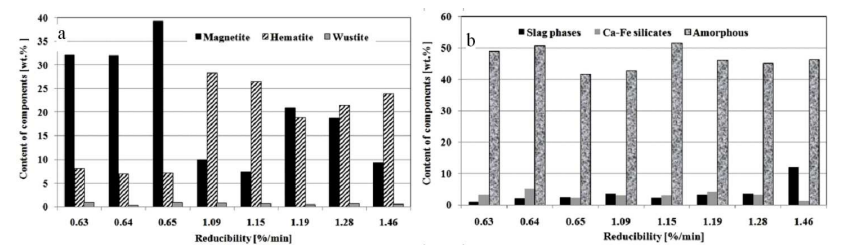

Fig. 4. The relation between reducibility and the content of different constituents of the sinters: (a) iron oxides, (b) Ca-Fe silicates, the slag phases and the amorphous phase.

The results showed the linear dependence between the magnetite and hematite contents and the reducibility of the sinters (Fig. 5) and no correlation between the reducibility and the amount of wustite. The content of wustite has not an important influence on the total value of reducibility. The increase of reducibility can be correlated with the lowering content of magnetite and the rising content of hematite. The total amount of cal- cium iron silicates (hedenbergite and kirschsteinite) has got the highest value for the sinter $2(x=5.1 \mathrm{wt} \%$, $R=0.64 \% / \mathrm{min})$ and the lowest value for the sinter 8 $(x=1.3$ wt $\%, R=1.46 \% / \mathrm{min})$ (Fig. $4 \mathrm{~b})$. The reverse tendency is observed for the slag phases - their smallest content - $1 \mathrm{wt} \%$ - was found in the sinter 1 $(R=0.63 \% / \mathrm{min})$ and the maximum value $-12.0 \mathrm{wt} \%$ — was reached in the sinter $8(R=1.46 \% / \mathrm{min})$. For both kinds of minerals, their fractions in the other sinters remained on the similar level. The dominant constituent of all examined sinters was the amorphous phase. No clear dependence can be formulated, but taking into account the level of the error value (about $2 \mathrm{wt} \%$ in each sinter) it can be concluded that the content of amorphous component remains almost constant in the sinters. In spite of the content of about $50 \mathrm{wt} \%$ of the amorphous phase, no characteristic broad peak was observed. It happens in some industrial materials that even $70 \mathrm{wt} \%$ of amorphous phase gives no contribution to the observed diffraction pattern as a diffuse maximum. The reason is that the chemical composition of the amorphous part is usually complex. It means that there is no possibility to form a local chemical bonding of two or three elements (mostly oxides) which can dominate the amorphous part so as to give a noticeable contribution to a diffraction pattern as a broad, intense peak. In fact, such a constituent can be thought as really amorphous with no short-range order. The only effect which is noticed in such systems is the significant decrease of the intensity of the observed full diffraction pattern in comparison to the observed one with lower content of the amorphous phase and the same set of crystalline phases.
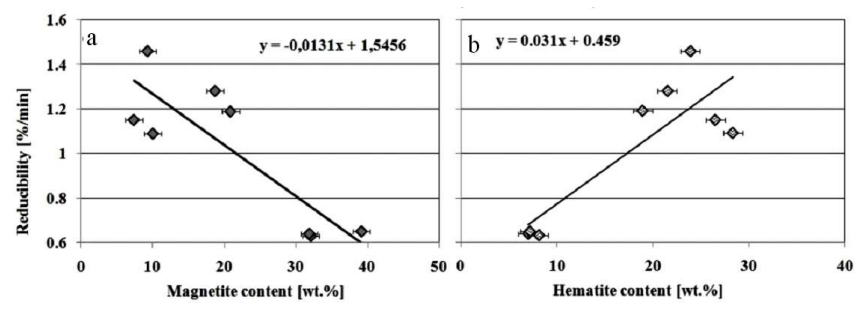

Fig. 5. The quantitative dependence of reducibility on mineralogical composition ((a) magnetite, (b) hematite).

\section{Acknowledgments}

The financial support from the statutory research project S0-0739 granted by the Ministry of Science and Higher Education, Republic of Poland is acknowledged.

\section{References}

[1] M. Matsumura, M. Hoshi, T. Kawaguchi, ISIJ Int. 45, 594 (2005).

[2] T. Umadevi, A. Brahmacharyulu, R. Sach, P.C. Mahapatra, M. Prabhu, Ironmak. Steelmak. 41, 270 (2014).

[3] E.A. Mousa, Ironmak. Steelmak. 41, 418 (2014). 
[4] J. Żebrok, T. Misiun, Report IMŻ No. S00452/BS/2003, 2003 (in Polish).

[5] M. Wyderko-Delekta, Outline of mineralogy of blastfurnace and steelmaking raw materials, 2nd ed., Wydawnictwo AGH, Kraków 1986 (in Polish).

[6] H.M. Rietveld, Acta Crystallogr. 22, 151 (1967).

[7] R.J. Hill, C.J. Howard, J. Appl. Crystallogr. 20, 467 (1987).

[8] SIROQUANT ${ }^{\mathrm{TM}}$ Quantitative XRD Software, Ver. 3.0 for Windows, 2007.
[9] U. König, T. Degen, N. Norberg, Powder Diffract. 29, S78 (2014).

[10] R.A. Young, in: The Rietveld Method, Ed. R.A. Young, Oxford University Press, New York 1993, p. 1.

[11] E. Prince, in: The Rietveld Method, Ed. R.A. Young, Oxford University Press, New York 1993, p. 43.

[12] J.C. Taylor, I. Hinczak, Rietveld Made Easy. A Practical Guide to the Understanding of the Method and Successful Phase quantifications, 2001. 